\title{
SPECIAL ISSUE: Technology-Based Pedagogical Approaches to Language Learning in Higher Education
}

\section{INTRODUCTION}

\section{Soraya García-Sánchez}

Universidad de Las Palmas de Gran Canaria

\section{Nicholas C. Burbules}

University of Illinois, Urbana-Champaign

The philosopher Ludwig Wittgenstein (1953) begins his Philosophical Investigations ${ }^{1}$ with a quote from Augustine's Confessions about how he first learned language:

When grown-ups named some object and at the same time turned towards it, I perceived this, and I grasped that the thing was signified by the sound they uttered, since they meant to point it out (§ 1).

Wittgenstein begins with this idea, the idea of ostensive definition, and pursues at length the question about what it means to learn a language, and what it means to be proficient in a language at a performative level. Through this question, he manages to elaborate a number of other important philosophical questions: whether there can be a "private language," how we can know the content of other people's minds, what it means to engage

Ludwig Wittgenstein \& Gertrude Elizabeth Margaret Anscombe. (1958). Philosophical investigations. Vol. 255. Oxford: Blackwell. 
successfully in any complex human practice (not only "language games"), and much more beyond the scope of the present discussion.

We begin with this point to highlight the idea that there is something especially important about language, and language learning, that is more than just the mastery of a set of skills or vocabulary. Learning a language means learning a culture (or in the case of second language learning, learning a new culture); it means learning to think in a certain way; it means learning how to create new phrasings, new meanings, and not only to follow patterns; it means making connections of significance between seemingly unrelated things - for example through metaphors and other figurative tropes. Learning language, in short, is essential to learning itself. That is why it is so important to Wittgenstein's investigations ${ }^{2}$.

One can go even further, and remember Heidegger's (2008) famous formulation: "we don't speak language, language speaks us ${ }^{3}$." We might prefer to say it as, "we speak language and language speaks us," but the idea that language is fundamentally constitutive of identity, sociality, and even the construction of the reality we experience runs deep in contemporary thought. If language has this fundamental role, then it relates to nearly everything we try to do and understand.

When we think, on the other hand, of new information and communication technologies as educational resources, a similar shift occurs: we need to go beyond thinking of technology as a tool we use, to ask about how technology uses us; to see how learning a new technology means learning a new culture; how it means learning to think in a certain way; how it means learning how to make new meanings, new connections of significance between seemingly unrelated things.

And so we are pleased to guest edit and present this collection of essays for Revista de Lenguas para Fines Específicos (LFE) on Technology-Based Pedagogical Approaches to Language Learning in Higher Education. The original call for papers asked for work that touched upon issues such as mobile and ubiquitous language learning; cooperation and collaboration; multimedia; " $21^{\text {st }}$ century" skills; personalized instruction; online language learning; assessment; and teacher education. In short, we were interested in the changing contexts, the

$2 \quad$ Michael A. Peters, Nicholas C. Burbules \& Paul Smeyers. (2008). Showing and Doing: Wittgenstein as a Pedagogical Philosopher. Boulder, Colorado: Paradigm Publishing, 2008. Revised and reissued with a new Preface and Postscript (2010).

$3 \quad$ Heidegger Martin. (2008). Way to language. Basic Writings (p. 413). London: Routledge. 
changing motivations, and the changing processes of language learning given the new possibilities of instructional technologies - but we also wanted to emphasize that these technologies were not just "delivery systems," but media that interact with and change the content of what is learned, as well as the intentions and purposes that drive language learning itself.

The first article of this monograph describes the general overview of MOOCs (Massive Online Open Courses) in Education, which is a relevant topic not only for foreign language acquisition but for different fields of education. Lojacono has pursued two main objectives. First, the author presents new forms of online formation, supported by independent learning, which opens the debate to the role of the instructor and the continuity in the current model of education. Second, the author discusses the advantages of MOOCs, emphasising the duality between teacher-student and a new model to learn and access knowledge linked to connectivism, which leaves organised thinking behind in order to face a complex way of thinking that is totally supported by ubiquitous knowledge.

Gimeno Sanz and Martínez Sáez explore how learning materials designed by language instructors often correspond and respond to their learners' needs. This fact fostered the creation of an upper-intermediate English language programme, InGenio FCE Online Course, which would be supported by technology and self-study approaches to address ESP (English for Specific Purposes) content for engineers at level B2 of the Common European Framework of References for Languages (CEFRL). This case study from the Universitat Politècnica de València reports positive results regarding learners' ESP improvement and motivation in a more dynamic Computer-Assisted Language Learning (CALL) process.

In this line, the integration of ICT in today's university language classrooms continues the discussion with the two following papers facing innovative pedagogical practices in Spanish as a Foreign Language (Español como Lengua Extranjera -ELE-) courses. On the one hand, Díaz and Hortiguera present some Technology-Enhanced Language Learning (TELL) pedagogical strategies to respond to current challenges in the intermediate Spanish language classes. An Action Research framework based on cognitive grammar and affective interactions has been implemented in order to analyse the use of PowerPoint in Spanish as a second/foreign language. It is argued that the pedagogical strategies implemented have experienced "technology as a means to an end rather than the end in itself", as the authors concluded. On the other hand, Dr. Mejía from the RMIT university in Australia reports positive outcomes of mobile learning in the Spanish foreign language classroom, which has pursued 
active interactions and independent learning. The results highlight that the production of the socio-cultural video using any mobile device has favored students' foreign language performance, although lack of technology support was a drawback for some learners.

Finally, to close this special issue, "Learning technologies and teamwork" is our contribution to share a more practical approach to $21^{\text {st }}$ century skills in higher education with LFE readers, having in mind ICT abilities, teamwork, and communication in foreign language courses. In line with Gimeno Sanz and Martínez Sáez, this last article focuses on EFL/ESP skills in learners in the field of Social Work. A distinction between (-e) cooperative and (e-) collaborative learning tasks is presented. The conclusions of this work suggest that active interactions set in a ubiquitous learning environment help to accomplish the communicative goals of the designed oral tasks. Ultimately, a reflection on the lifelong learning (LLL) philosophy that links different stages of education is proposed for a $21^{\text {st }}$ century educational community forming professionals for their future workplace. 